\title{
Protection of BALB/c mice against experimental Helicobacter pylori infection by oral immunisation with $H$. pylori heparan sulphate-binding proteins coupled to cholera toxin $\beta$-subunit
}

\author{
E. RUIZ-BUSTOS, A. SIERRA-BELTRAN, M.J. ROMERO, C. RODRIGUEZ-JARAMILLO* and \\ F. ASCENCIO
}

Department of Marine Pathology and *Histology Laboratory, Center for Biological Research, La Paz, Baja California Sur 23000, Mexico

\begin{abstract}
The presence of Helicobacter pylori in the gastroduodenal mucosae is associated with chronic active gastritis, peptic ulcers and gastric cancers such as adenocarcinoma and low-grade gastric B-cell lymphoma. In response to the presence of antibiotic-resistant strains, the use of vaccines to combat this infection has become an attractive alternative. The present study used a murine model of infection by a mouse-adapted $H$. pylori strain to determine whether infection in BALB/c mice can be successfully eradicated by intragastric vaccination with $H$. pylori heparan sulphate-binding proteins (HSBP) covalently coupled to the $\beta$-subunit of cholera toxin (CTB). It was shown that vaccination confers protection against exposure of $B A L B / c$ mice to the pathogen, as revealed by microbiological, histopathological and molecular methods.
\end{abstract}

\section{Introduction}

The presence of Helicobacter pylori in human gastric mucosa is now established as the aetiological agent of chronic gastritis and most cases of peptic ulcer and gastric adenocarcinoma world-wide [1-5] and is considered as a class I carcinogen [6] by the World Health Organization.

Experimental infection of volunteers has shown that individuals develop severe polymorphonuclear leucocyte inflammation of the mucosa as a consequence of exposure to $H$. pylori [7], with the presence of immunoglobulin A (IgA) and $\operatorname{IgG}$ class antibodies. Nevertheless, this response fails to eradicate the bacteria and, although evidence exists of spontaneous eradication by the host, most untreated individuals remain infected with the organism, developing a chronic gastritis [5] characterised by gastric lymphoid tissue.

Current treatment of peptic ulcer disease consists of

Received 20 April 1999; revised version received 10 July 1999; accepted 13 Sept. 1999.

Corresponding author: Dr F. Ascencio (e-mail: ascencio@, cibnor.mx). acid suppression and antimicrobial therapy [8]. Although current treatment regimens are effective and the incidence of re-infection is low in industrialised countries, re-infection and recrudescence in the developing world are significant problems [9]. On the other hand, the emergence of antibiotic-resistant strains, poor patient compliance and the high cost of therapy and patient management represent additional problems for management of $H$. pylori-infected individuals, especially in the developing world, where antimicrobial treatment [6] has not been very effective.

In 1991, Karita and colleagues established transient $H$. pylori infections in immunodeficient $\mathrm{BALB} / \mathrm{c}$ mice, thus demonstrating for the first time that it was possible to colonise a small laboratory animal with $H$. pylori [10]. More recently, there have been reports of the colonisation of immunocompetent mice with mouseadapted $H$. pylori isolates [11]. Marchetti et al. used a mouse-adapted strain to study the immunoprotection of $\mathrm{BALB} / \mathrm{c}$ mice against this gastrointestinal pathogen, so providing a suitable animal model for studying the pathology of $H$. pylori [12]. By screening various clinical isolates of $H$. pylori for their ability to colonise mice, Lee and colleagues [13] identified one $H$. pylori strain (SS1) [7] that, after adaptation to mice, was able to colonise the mouse gastric mucosae in high numbers for up to 8 months. 
In previous studies, significant protection against challenge with different species of Helicobacter has been demonstrated when various antigenic mixtures were co-administered by a mucosal route with a suitable adjuvant [14-19]. In those studies, vaccine antigens were found to induce protection against challenge. Although its role was not clearly defined, they suggested that antigen-specific secretory $\operatorname{IgA}$ (sIgA) can protect against infection. A role for sIgA in protection against $H$. pylori infection $[11,15]$ has been suggested with studies on passive immunity where human breast milk IgA titres were shown to correlate with a delay in the onset of $H$. pylori infection in infants.

Previous studies have shown that $H$. pylori expresses cell surface-associated proteins (outer-membrane proteins, OMP) and extracellular proteins (heat-shock bacterial proteins HSBP) which have affinity for the glucosaminoglycan heparan sulphate (Ruiz-Bustos et $a l$., unpublished data). It was also found that oral immunisation of BALB/c mice with HSBP elicited a specific mucosal and systemic immune response (RuizBustos et al., unpublished data). Therefore, the present study is focused on the application of a HSBP-based vaccine to protect $\mathrm{BALB} / \mathrm{c}$ mice against experimentally induced infection with a mouse-adapted $H$. pylori strain.

\section{Materials and methods}

\section{Bacteria and growth conditions}

The mouse-adapted H. pylori strain 25 was obtained from the gastric mucosa of BALB/c mice by repeated in-vivo passages through oral administration of $5 \times 10^{8} \mathrm{cfu}$ (in $0.5 \mathrm{ml}$ ) of $H$. pylori [12]. After 10 days, mice were killed by cervical vertebral dislocation under light anaesthesia; stomach and small intestine were excised and homogenised in PBS. Then, $250 \mu \mathrm{l}$ of this suspension was cultured in GAB-Camp medium supplemented with human blood $8.5 \%$ and horse serum $10 \%$ and the following antibiotics: vancomycin $100 \mu \mathrm{g} / \mathrm{ml}$, amphotericin B $50 \mu \mathrm{g} / \mathrm{ml}$ and nalidixic acid $10.7 \mu \mathrm{g} / \mathrm{ml}$. Plates were incubated for $48 \mathrm{~h}$ and $H$. pylori colonies were identified by morphology and confirmed by positive rapid urease reaction. The $H$. pylori strain had been passaged through mice up to eight times before its use in the present experiment.

\section{Immunogen preparation}

Briefly, HSBP and cholera toxin $\beta$-subunit (CTB) were each coupled to N-succinimidyl-(3-[2-pyridyl]-dithio) propionate (SPDP) at molar ratios of $1: 30$ and $1: 10$, respectively, according to the manufacturer's instructions (Pharmacia). The HSBP derivative was reduced with dithiothreitol in $0.1 \mathrm{M}$ sodium acetate buffer$0.1 \mathrm{M} \mathrm{NaCl}, \mathrm{pH}$ 4.5. The resulting HSBP preparation was incubated in equimolar proportions with the adjuvant for $16 \mathrm{~h}$ at $22^{\circ} \mathrm{C}$. The mixture was dialysed extensively against $0.01 \mathrm{M}$ phosphate-buffer- $0.15 \mathrm{M}$ $\mathrm{NaCl}, \mathrm{pH} 7.4$.

\section{Immunisation of mice}

Eight-week old BALB/c mice were housed in polycarbonate cages in isolators and fed a commercial pellet diet with water ad libitum. Three groups of 15 mice each were immunised orally via feeding needles, with a priming dose on day 0 and booster doses on days 10 and 20, as follows: group I HSBP-CTB $20 \mu \mathrm{g}$; group II $0.2 \mathrm{M} \mathrm{NaHCO}_{3}$ and group III saline only.

\section{Experimental infections in mice with the mouse- adapted $H$. pylori strain}

Ten days after the last immunisation, mice were exposed to an experimental infection with a mouseadapted $H$. pylori suspension $\left(5 \times 10^{8}\right.$ cells $)$ administered orally with feeding needles as described above with the exception of the group treated with saline, which remained uninfected. At 15-day intervals, five mice from each group were anaesthetised, blood was taken by heart puncture and gastric tissue was taken for further testing.

\section{Isolation of $H$. pylori}

Two biopsy specimens (body and antral regions of the gut) were collected from each animal for bacterial culture as described previously [20], plated on solid GAB-Camp medium and incubated for $48 \mathrm{~h}$ at $37^{\circ} \mathrm{C}$ in $\mathrm{CO}_{2} 5 \%$ in air. $H$. pylori was identified as gramnegative, curved bacteria, catalase, oxidase and urease positive.

\section{Identification of $H$. pylori cells in H. pylori- infected mice}

H. pylori cells were identified by three different approaches.

Rapid urease test. Biopsy samples from the body and antral regions of each stomach were placed into tubes containing urea agar. The tubes were incubated at $37^{\circ} \mathrm{C}$ for up to $8 \mathrm{~h}$; development of a pink colour, was indicative of a positive test.

Histopathology. Biopsy samples from the body and antral regions of the stomach were placed in buffered formalin $10 \%$. These samples were embedded in paraffin, cut into $5-\mu \mathrm{m}$ thick sections and stained with the Warthin-Starry silver stain to detect the presence of H. pylori cells. Similarly, 5- $\mu \mathrm{m}$ thick tissue sections were stained with haematoxylin and eosin to measure histopathological alterations in the stomach mucosa.

$P C R$. Biopsies taken from the body and antral region of each stomach were placed in a solution containing 
brucella broth $70 \%$, fetal bovine serum $20 \%$ and glycerol $10 \%$. Samples were frozen at $-70^{\circ} \mathrm{C}$ until required for DNA analysis. From these frozen samples (c. $15 \mathrm{mg}$ of tissue), DNA was extracted as described previously [21]. Briefly, each biopsy sample was ground in $500 \mu \mathrm{l}$ of Brucella broth for $10 \mathrm{~s}$, transferred to a microcentrifuge tube and centrifuged for $5 \mathrm{~min}$ at $10000 \mathrm{rpm}$. The supernate was discarded and the DNA was extracted by consecutive treatment with lysozyme $4 \mathrm{mg} / \mathrm{ml}$, SDS $10 \%$ and proteinase $\mathrm{K} 10 \mathrm{mg} / \mathrm{ml}$. DNA was purified by the phenol:chloroform:isoamyl alcohol (25:24:1) procedure and precipitated with ice-cold ethanol. PCR amplification of $H$. pylori DNA and selection of primers were based on previously published data [21-23]. The primers used were those coding for the urease enzyme of $H$. pylori.

Briefly, between 12 and $18 \mu \mathrm{l}$ of the DNA preparation were added to $100 \mu \mathrm{l}$ (final volume) of the reaction mixture containing $1 \times$ Taq polymerase supplemented with $1 \mathrm{M} \mathrm{MgCl}_{2}$ (final concentration $2.25 \mathrm{mM}$ ), the two primers (each $0.5 \mu \mathrm{M}$ ) and deoxynucleotides (each $200 \mu \mathrm{M}$ ). The forward primer contained the sequence 5' (AAGCTTTTAGGGGTGTTAGGGGTTT)-3' and the reverse primer the sequence $5^{\prime}$ (AAGCTTACTTTC TAACACTAACGC) 3', derived from the H. pylori ureC gene sequence (accession numbers, EMBL X57132 and GenBank M60398), which amplify a 249-bp DNA fragment [21]. Samples were heated at $94^{\circ} \mathrm{C}$ for $4 \mathrm{~min}$, centrifuged, and cooled to $65^{\circ} \mathrm{C}$. Thirty cycles of amplification were performed in a DNA thermal cycler (GeneAmp system; Perkin-Elmer Cetus). Each cycle consisted of a $45-\mathrm{s}$ denaturation step at $94^{\circ} \mathrm{C}$, a $30-\mathrm{s}$ annealing step at $59^{\circ} \mathrm{C}$ and a 90 -s extension step at $72^{\circ} \mathrm{C}$. The final cycle included an extension step $\left(10 \mathrm{~min}\right.$ at $\left.72^{\circ} \mathrm{C}\right)$ to ensure full extension of the product. A DNA preparation from H. pylori was used as the positive control in each batch of PCR assays and distilled water in place of the DNA samples was used as a negative control.

\section{Determination of serum, mucus and biliary antibody levels to $H$. pylori}

Blood was obtained by cardiac puncture of anaesthetised mice prior to necropsy, sera were collected and stored at $-20^{\circ} \mathrm{C}$ until assay. The small intestine and gall bladder were excised, extracting intestinal mucus and bile for antibody measurements. The determination was performed on 96-well ELISA plates coated with $10 \mu \mathrm{g}$ of HSBP/well. Serum (100 $\mu$ l diluted 1 in 100), bile and mucus (100 $\mu$ l diluted 1 in 10$)$ were added and incubated for $90 \mathrm{~min}$ at $37^{\circ} \mathrm{C}$. After incubation, the wells were washed with PBS-Tween and the plates were incubated at $37^{\circ} \mathrm{C}$ for $90 \mathrm{~min}$ with $100 \mu \mathrm{l}$ of a 1 in 1000 dilution (stock concentration of $0.5 \mathrm{mg} / \mathrm{ml}$ ) of rabbit anti-mouse IgG- or IgA-horseradish peroxidase conjugates (Sigma). After washing with PBS-Tween, plates were developed with $o$-phenylene diamine as the substrate. The plates were then read at $492 \mathrm{~nm}$.

\section{Results}

\section{Mouse-adapted H. pylori strain}

By means of consecutive passage through BALB/c mice intestinal tracts, $H$. pylori was able to adhere to the mouse gut-mucosal tissue, as revealed by histological examination. An interesting observation was that through subculture of the bacteria, the reaction in the urease test was slower than in the adapted strain, which gave a more rapid response in this test.

\section{Isolation of $H$. pylori}

After $48 \mathrm{~h}$ culture of tissue homogenates in GAB-Camp medium, individual, pinpoint, clear colonies were observed. Colonies were confirmed as H. pylori if they were urease, catalase and oxidase positive and if during microscopical examination the cells were gramnegative and had the characteristic curved-rod appearance. H. pylori was isolated from two $(13 \%)$ of the 15 $\mathrm{BALB} / \mathrm{c}$ mice orally immunised with the HSBP-CTB conjugate, while all $15(100 \%)$ of the unvaccinated group were positive for $H$. pylori.

\section{Identification of $H$. pylori cells in H. pylori- infected mice}

Urease testing. The rapid urease tests were positive for the antrum from all animals of the non-immunised group after incubation for $8 \mathrm{~h}$ at $37^{\circ} \mathrm{C}$ in $\mathrm{CO}_{2} 5 \%$. However, only one animal $(6.6 \%)$ of the immunised group had evidence of the presence of $H$. pylori, as determined by this test.

Histopathology. Nineteen longitudinal biopsies were evaluated for the presence of $H$. pylori cells (Fig. 1). In the vaccinated group, no bacteria could be determined in $93.4 \%$ of animals orally immunised with the HSBPCTB conjugate, whereas in the placebo group, stained tissue revealed numerous $H$. pylori organisms on the surface of the gastric epithelia and on the surface of the epithelial lining of the glandular crypts (Fig. 1). It was interesting that although the bacteria could be detected in the gastric pits and were associated with mucussecreting cells, no evidence of gross lesions on the gastric mucosa could be observed in either the infected or the immunised mice.

PCR. The PCR assay successfully amplified a fragment of the expected $249 \mathrm{bp}$ from a DNA preparation of the mouse-adapted $H$. pylori strain 25 with the UreC primers. When genomic DNAs prepared from the gastric tissue specimens were used as templates, the PCR assay yielded DNA fragments of the same mol. wt as that obtained from the H. pylori strain (Fig. 2). Of the immunised group, 14 animals were found to be free of the pathogen, whilst in the unvaccinated group PCR analysis showed that all the animals were infected. 


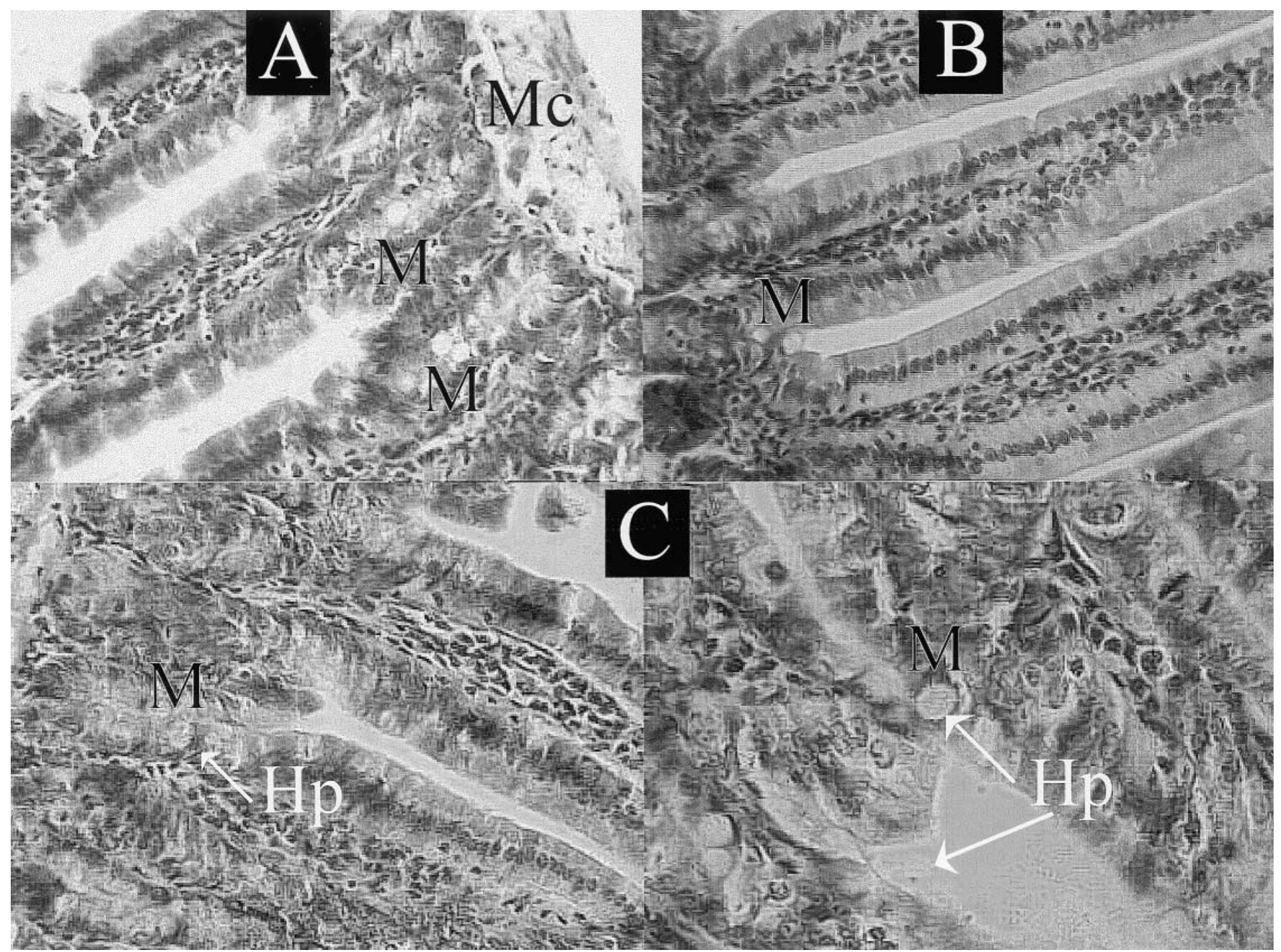

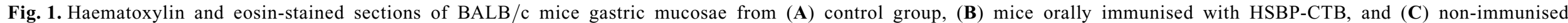
mice. The presence of the bacteria (arrow) was determined by the detection of spiral rods within the mucus secretory cells (M) and in the mucosal crypts (MC). 


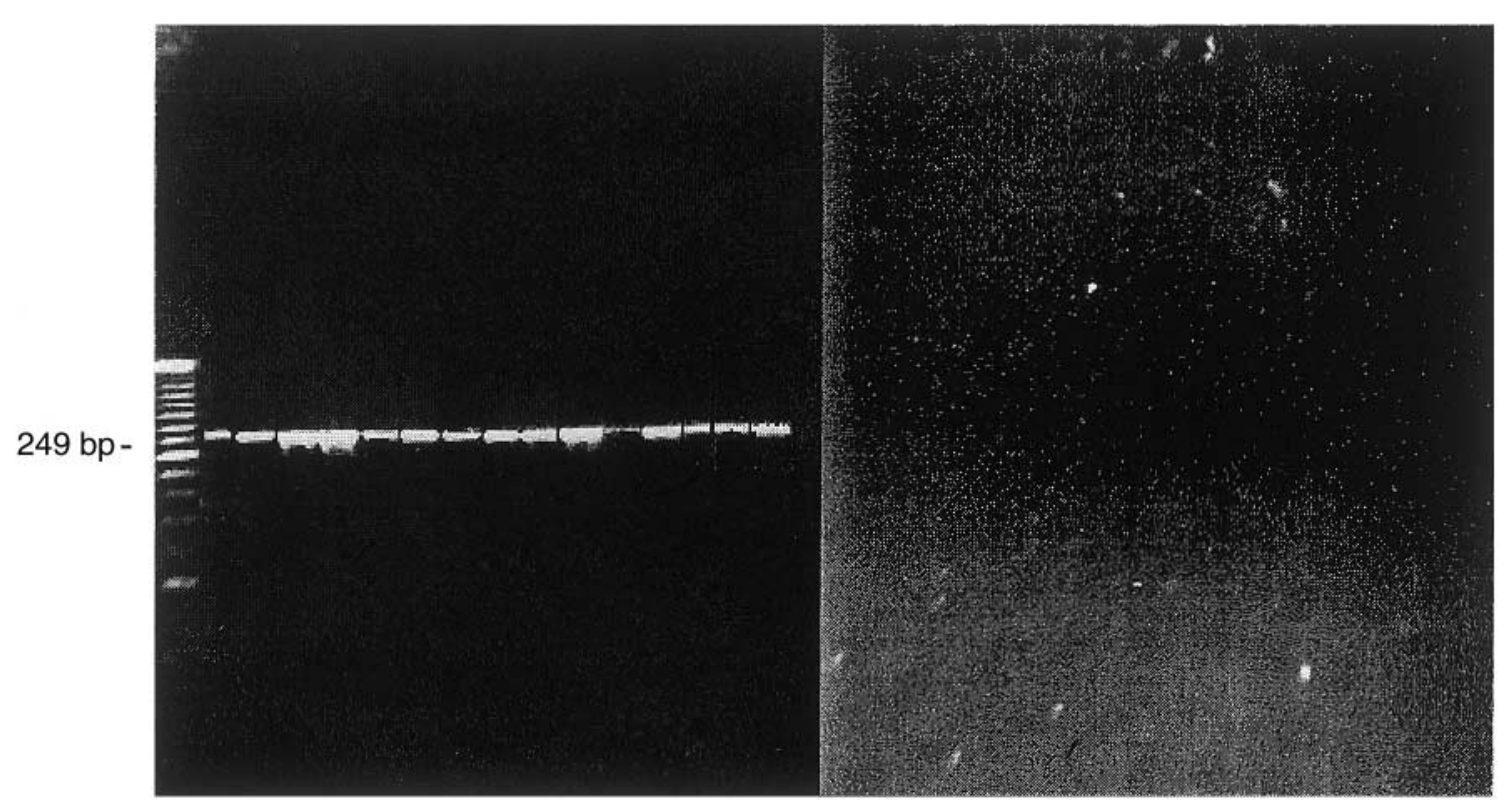

Fig. 2. PCR detection of H. pylori UreC fragment in gastrointestinal tract of (a) unvaccinated and (b) vaccinated $\mathrm{BALB} / \mathrm{c}$ mice.

Serum, biliary and local gastric immune response

High levels of IgG anti-HSBP of H. pylori were found in sera from immunised mice, while the serum IgA response was not as high, yet significantly greater than that found in the placebo group (Fig. 3). The mucosal IgA immune response against $H$. pylori HSBP was detected in the serum of immunised mice, as well as in intestinal mucus and biliary secretions (Fig. 3).

\section{Protection against experimentally induced $H$. pylori infection}

Mice orally immunised with HSBP covalently coupled to CTB were significantly protected against challenge with mouse-adapted $H$. pylori $(\mathrm{p}<0.005)$, as revealed by impairment of adhesion and colonisation of the murine stomach by mouse-adapted H. pylori cells, determined by rapid urease test, microbiological culture and PCR evaluations, in comparison with sodium bicarbonate-immunised controls. No significant differences were observed at any of the time points after infection, either in the presence of anti-HSBP antibodies (Fig. 4) or in the number of mice infected with the bacterium (Table 1).

\section{Discussion}

Although 15 years have elapsed since the discovery of $H$. pylori, an effective antimicrobial monotherapy or vaccine against $H$. pylori has not been fully developed.

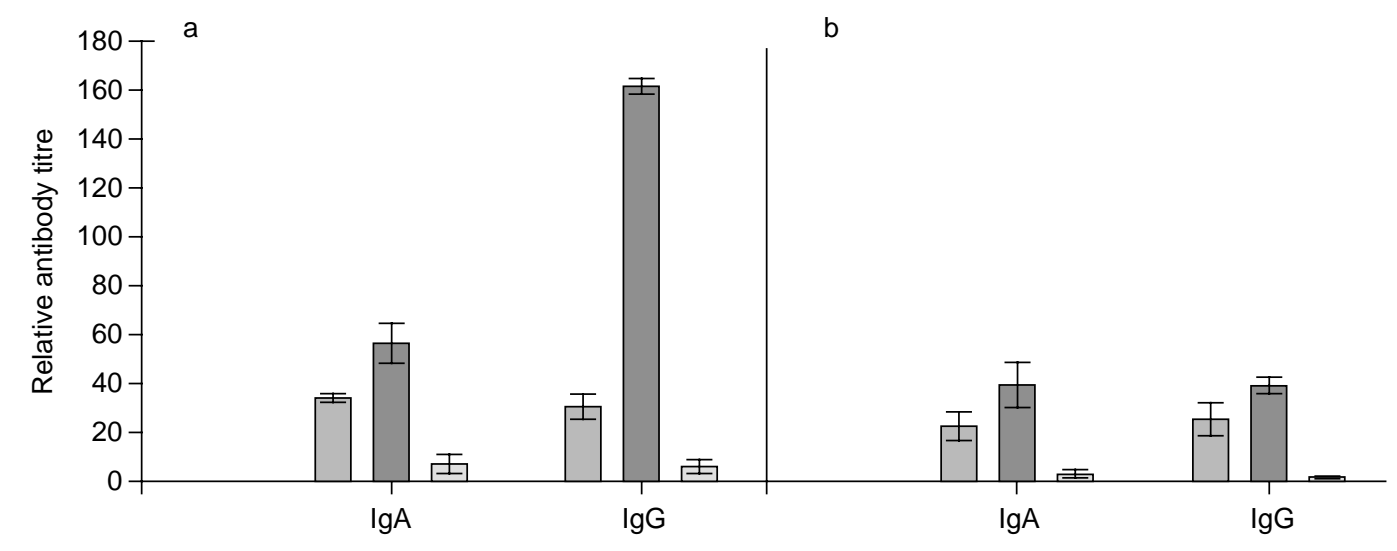

Fig. 3. Antibody responses in sera ( $\square$ ), bile ( $\square$ ), and gastric secretions $(\square)$ of BALB/c mice under different treatments. The bar shows the mean (SEM) $\mathrm{OD}_{492}$ from a group of 15 mice. 


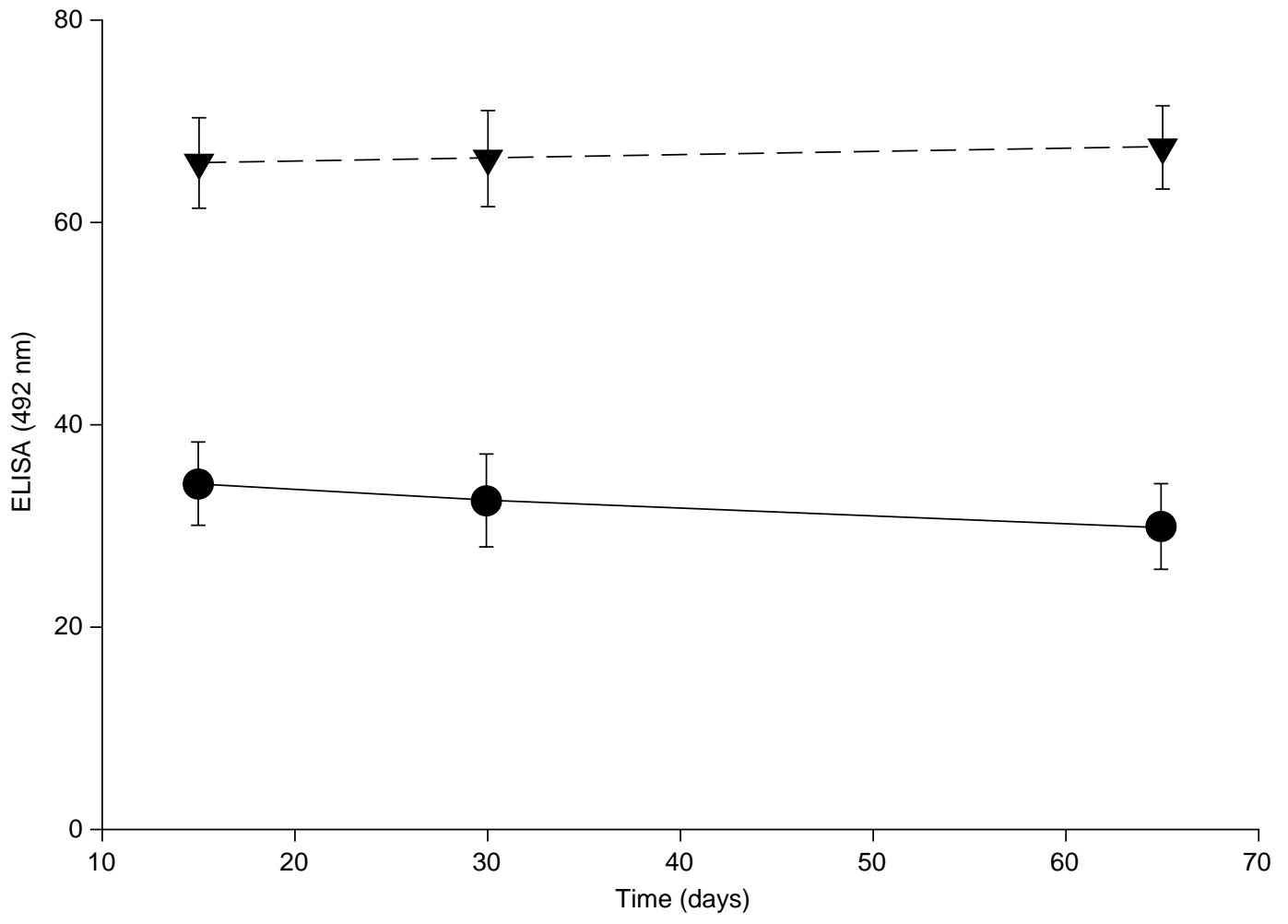

Fig. 4. Mean (SEM) antibody titre at three time points after infection of BALB/c mice orally immunised with HSBPCTB.

Table 1. H. pylori detection after challenge of orally immunised and untreated $\mathrm{BALB} / \mathrm{c}$ mice

\begin{tabular}{lcccc}
\hline \multirow{2}{*}{$\begin{array}{l}\text { Treatment } \\
\text { (number of mice) }\end{array}$} & \multicolumn{4}{c}{ Number (\%) of mice positive for H. pylori by } \\
\cline { 2 - 5 } & Rapid urease test & Culture & Histopathology & PCR \\
\hline HSBP-CTB (15) & $1(6.6)$ & $2(13)$ & $1(6.6)$ & $1(6.6)$ \\
Placebo (15) & $15(100)$ & $14(93)$ & $15(100)$ & $15(100)$ \\
Uninfected mice (15) & $0(0)$ & $0(0)$ & $0(0)$ & $0(0)$ \\
\hline
\end{tabular}

This is a most important goal to achieve, given the pathogenic potential of the bacteria in man. Besides man, domestic cats and non-human primates are the only animals in which $H$. pylori has been found to occur normally with subsequent histopathological damage [24]. Distinct animal models such as the rhesus monkey and Mongolian gerbils have been proposed. Marchetti and co-workers [12] used a murine model to evaluate a vaccine consisting of VacA and hLT (Escherichia coli thermolabile toxin), effectively preventing infection with virulent strains of $H$. pylori.

Different studies have shown that heparin, heparan sulphate (HS) and other glycosaminoglycans (GAGs) are involved in the binding of some specific viruses and pathogenic microbes to eukaryotic cells [25, 26]. The binding of heparan sulphate glucosaminoglycan to H. pylori cells has been proposed as a putative candidate for anti-adhesion therapy [27], and in this study, the protective role of the HSBP-CTB immuno- gen was assessed in orally immunised BALB/c mice challenged with a mouse-adapted $H$. pylori strain.

Culture, considered specific for $H$. pylori although not sensitive, detected the bacterium in all the experimentally infected mice which had not received anti- $H$. pylori treatment. In this non-immunised group, Helicobacter-like colonies could be obtained consisting of gram-negative rods, that were catalase, oxidase and urease positive. In contrast, bacteria could be detected in only two $(13 \%)$ of the immunised mice. As it is considered that studies relying on culture as the sole diagnostic method may underestimate the prevalence of H. pylori, other diagnostic methods were used.

Histological examination was positive for $H$. pylori in one of the 15 mice orally immunised with the HSBPCTB immunogen, in contrast to the non-immunised group, where the bacteria could be recovered from $100 \%$ of the animals exposed to the pathogen. 
Interestingly, these animals did not show signs of gastritis (Fig. 3), consistent with previous observations of the BALB/c mouse model [12], where although mice were positive for anti-H. pylori antibodies and the presence of the bacteria, no gastric inflammation was detected.

The absence of gastritis in $H$. pylori-infected mice might be due to the absence of certain pathways involved in the induction of inflammatory responses in the human gastric mucosa [7,28]. For instance, mice do not produce a homologue of the human proinflammatory cytokine interleukin-8 (IL-8), identified as playing an integral role in the recruitment and activation of inflammatory cells in the gastric mucosae of $H$. pylori-infected individuals. On the basis of studies with murine Helicobacter models, it has been proposed that host factors (dietary requirements, cytokines), and not bacterial strain differences $[29,30]$, are the major factors contributing to the pathology associated with $H$. pylori infection.

The findings presented here suggest that the HSBPCTB immunogen is able to prevent $H$. pylori infection in BALB/c mice, blocking the HSBP adhesins of $H$. pylori, thus preventing the adhesion of the bacteria to the gastric cells. With this mechanism of defence, the mouse is able to wash out any non-adherent bacteria by means of normal mucosal turnover.

This work was supported by the Center for Biological Research, CIBNOR (RB3). E. R-B. was the recipient of a CONACyT scholarship from the Mexican Government. We thank Dr Ellis Glazier for editorial revision of the text.

\section{References}

1. Blaser MJ. Helicobacter pylori and the pathogenesis of gastroduodenal inflammation. J Infect Dis 1990; 161: 623-633.

2. Clyne M, Drumm B. Adherence of Helicobacter pylori to primary human gastrointestinal cells. Infect Immun 1993; 61: 4051-4057.

3. Kobayashi Y, Okazaki K-I, Murakami K. Adhesion of Helicobacter pylori to gastric epithelial cells of primary cultures obtained from stomachs of various animals. Infect Immun 1993; 61: 4058-4063.

4. Lee A, Hazell SL. Campylobacter pylori in health and disease: an ecological perspective. Microb Ecol Health Dis 1988; 1: $1-16$.

5. Mai UEH, Perez-Perez GI, Allen JB, Wahl SM, Blaser MJ Smith PD. Surface proteins from Helicobacter pylori exhibit chemotactic activity for human leukocytes and are present in gastric mucosa. J Exp Med 1992; 175: 517-525.

6. Kleanthous H, Myers GA, Georgakopoulos KM et al. Rectal and intranasal immunizations with recombinant urease induce distinct local and serum immune responses in mice and protect against Helicobacter pylori infection. Infect Immun 1998; 66: 2879-2886.

7. Ferrero RL, Thilberge J-M, Huerre M, Labigne A. Immune responses of specific-pathogen-free mice to chronic Helicobacter pylori (strain SS1) infection. Infect Immun 1998; 66: 1349-1355.

8. Malfertheiner P. Compliance, adverse events and antibiotic resistance to Helicobacter pylori treatments. Scand J Gastroenterol 1993; 28 Suppl 196: 34-37.

9. Crabtree JE, Shallcross TM, Wyatt JI et al. Mucosal humoral immune response to Helicobacter pylori in patients with duodenitis. Dig Dis Sci 1991; 36: 1266-1273.
10. Lee A, Chen M. Successful immunization against gastric infection with Helicobacter species: use of a cholera toxin Bsubunit-whole-cell vaccine. Infect Immun 1994; 62: 35943597.

11. Ghiara P, Rossi M, Marchetti M et al. Therapeutic intragastric vaccination against Helicobacter pylori in mice eradicates an otherwise chronic infection and confers protection against reinfection. Infect Immun 1997; 65: 4996-5002.

12. Marchetti M, Aricó B, Burroni D, Figura N, Rappuoli R, Ghiara P. Development of a mouse model of Helicobacter pylori infection that mimics human disease. Science 1995; 2678: $1655-1658$.

13. Lee CK, Weltzin R, Thomas WD et al. Oral immunization with recombinant Helicobacter pylori urease induces secretory IgA antibodies and protects mice from challenge with Helicobacter felis. J Infect Dis 1995; 172: 161-172.

14. Corthésy-Theulaz IE, Hopkins S, Bachmann D et al. Mice are protected from Helicobacter pylori infection by nasal immunization with attenuated Salmonella typhimurium phoP expressing urease A and B subunits. Infect Immun 1998; 66: $581-586$.

15. Czinn SJ, Cai A, Nedrud JG. Protection of germ-free mice from infection by Helicobacter felis after active oral or passive IgA immunization. Vaccine 1993; 11: 637-642.

16. Dubois A, Lee CK, Fiala N, Kleanthous H, Mehlman PT, Monath T. Immunization against natural Helicobacter pylori infection in nonhuman primates. Infect Immun 1998; 66: 4340-4346.

17. Ferrero RL, Thiberge J-M, Kansau I, Wuscher N, Huerre M, Labigne A. The GroEShomolog of Helicobacter pylori confers protective immunity against mucosal infection in mice. Proc Natl Acad Sci USA 1995; 92: 6499-6503.

18. Pappo J, Thomas WD, Kabok Z, Taylor NS, Murphy JC, Fox JG. Effect of oral immunization with recombinant urease on murine Helicobacter felis gastritis. Infect Immun 1995; 63: 1246-1252.

19. Radcliff FJ, Hazell SL, Kolesnikow T, Doidge C, Lee A. Catalase, a novel antigen for Helicobacter pylori vaccination. Infect Immun 1997; 65: 4668-4674.

20. Handt LK, Fox JG, Yan LL et al. Diagnosis of Helicobacter pylori infection in a colony of rhesus monkeys (Macaca mulatta). J Clin Microbiol 1997; 35: 165-168.

21. Monteiro L, Cabrita J, Mégraud F. Evaluation of performances of three DNA enzyme immunoassays for detection of Helicobacter pylori PCR products from biopsy specimens. J Clin Microbiol 1997; 45: 2931-2936.

22. Hammar M, Tyszkiewicz T, Wadström T, O’Toole PW. Rapid detection of Helicobacter pylori in gastric biopsy material by polymerase chain reaction. J Clin Microbiol 1992; 30: 54-58.

23. Yoshida H, Hirota K, Shiratori Y et al. Use of gastric juicebased PCR assay to detect Helicobacter pylori infection in culture-negative patients. J Clin Microbiol 1998; 36: 317-320.

24. Neiger R, Dieterich C, Burnens A et al. Detection and prevalence of Helicobacter infection in pet cats. $J$ Clin Microbiol 1998; 36: 634-637.

25. Frevert U, Sinns P, Cerami C, Shreffler W, Takacs B, Nussenzweig V. Malaria circumsporozoite protein binds to heparan sulphate proteoglycans associated with the surface membrane of hepatocytes. J Exp Med 1993; 177: 1287-1298.

26. Utt M, Wadström T. Identification of heparan sulphate binding surface proteins of Helicobacter pylori: inhibition of heparan sulphate binding with sulphated carbohydrate polymers $J$ Med Microbiol 1997; 46: 541-546.

27. Ljungh A, Moran APm Wadström T. Interactions of bacterial adhesins with extracellular matrix and plasma proteins: pathogenic implications and therapeutic possibilities. FEMS Immunol Med Microbiol 1996; 16: 117-126.

28. Wirth H-P, Beins MH, Yang M, Tham KT, Blaser MJ. Experimental infection of Mongolian gerbils with wild-type and mutant Helicobacter pylori strains. Infect Immun 1998; 66: 4856-4866.

29. Sakagami T, Dixon M, O'Rourke J et al. Atrophic gastric changes in both Helicobacter felis and Helicobacter pylori infected mice are host dependent and separate from antral gastritis. Gut 1996; 39: 639-648.

30. Shomer NH, Dangler CA, Whary MT, Fox JG. Experimental Helicobacter pylori infection induces antral gastritis and gastric mucosa-associated lymphoid tissue in guinea pigs. Infect Immun 1998; 66: 2614-2618. 